\title{
Students Higher Order Thinking Skills: Analyze, Evaluate, Create Green Consumerism Solution in Environmental Learning
}

\author{
IImi Zajuli Ichsan ${ }^{1, a^{*}}$, Diana Vivanti Sigit ${ }^{1, b}$, Mieke Miarsyah ${ }^{1, c}$ \\ ${ }^{1}$ Biology Education Program, Faculty of Mathematics and Natural Sciences, Universitas Negeri Jakarta, Indonesia \\ a ilmizajuli95@gmail.com; b dianav@unj.ac.id; ‘ mmiarsyah@unj.ac.id \\ ${ }^{*}$ Corresponding Author
}

How to Cite: Ichsan, I. Z., Sigit, D. V., \& Miarsyah, M. (2019). Students Higher Order Thinking Skills: Analyze, Evaluate, Create Green Consumerism solution in Environmental Learning. International Journal for Educational and Vocational Studies, 1(4), 308-313

\section{ARTICLE HISTORY}

Received: 13 May 2019

Revised: 22 June2019

Accepted: 5 August 2019

\section{KEYWORDS}

Green Consumerism; Environmental learning; Higher Order Thinking Skills; Profile;

\begin{abstract}
Environmental learning in schools should be based on Higher Order Thinking Skills (HOTS) and based on environmental problems, one of which is Green Consumerism (GC). The problem is the absence of student HOTS profiles based on GC. The purpose of this study was to measure students HOTS based on GC concepts and present them descriptively in the form of profiles. The study was conducted in November-December 2018 at State Junior High School 1 in South Tambun, Bekasi, West Java, Indonesia. The research method used is descriptive research. The sample used was 128 students in grade $8^{\text {th }}$, consisting of 42 male students and 86 female students. The results showed that GC-based HOTS scores were still relatively low. Students overall got an average score of 31.55. The aspect with the highest score was obtained in the analyze (C4) aspect with a score of 3.81 , while the aspect with the lowest score was on the create aspect (C6) with a score of 2.57 . This is because the information about GC is still not obtained by many students. The conclusion is that students' HOTS scores are low and need to be improved.
\end{abstract}

This is an open access article under the CC-BY-SA license.

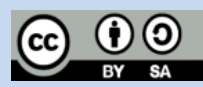

\section{INTRODUCTION}

Environmental learning in schools can stand alone or it can also be part of learning Biology or Science. Environmental learning in the 21st century is no longer talking about various concepts in the book, but has turned to the study of current issues. One of them is the issue of Green Consumerism (GC). The principles of GC is held by someone in consuming an item based on environmentally friendly aspects are the essence of GC (Costa, Montemurro, \& Giuliani, 2018; Gu, Chhajed, Petruzzi, \& Yalabik, 2015; McCarthy \& Liu, 2017). In learning it rarely touches on this GC issue. In 21st century learning, especially in environmental learning at the secondary school level, discussions are needed on environmental issues. This is because it is more relevant for students in order to solve environmental problems (Derman, Sahin, \& Hacieminoglu, 2016; Kartikaningtyas, Kusmayadi, \& Riyadi, 2018; Koutsoukos, Fragoulis, \& Valkanos, 2015). GC can be interpreted specifically in the context of students, as a concept of a student who consumes environmentally friendly goods to preserve the environment (Akenji, 2014; Meyer, 2016; Shabani, Ashoori, Taghinejad, \& Beyrami, 2013; Watson, Hegtvedt, Johnson, Parris, \& Subramanyam,
2017). The GC discussed in this study is the behavior of students in consuming various daily needs such as energy consumption, use of plastic, etc. Students in solving environmental problems in this case GC problems really need the ability to analyze, evaluate, and create. This ability is often known as Higher Order Thinking Skills (HOTS). This ability is needed by students to solve various problems that exist in their environment (Anderson et al., 2001; Jensen, McDaniel, Woodard, \& Kummer, 2014; Narayanan \& Adithan, 2015).

The problem that arises is, incomplete data available regarding HOTS on the GC topic. This resulted in the development process becoming difficult, because there was no student HOTS profile in terms of GC. The studies that have been conducted with regard to HOTS discuss more about students' HOTS on very conventional topics, not many of them discuss it in terms of being based on current environmental issues (Gündüz, Alemdağ, Yaşar, \& Erdem, 2016; S. M. Lee, 2014; Saido, Siraj, Nordin, \& Amedy, 2015). The research that discusses the HOTS profile of students in terms of GC has never been done. Therefore, this research offers novelty in the form of HOTS profiles of students in terms of GC. Based on these problems, the purpose of this 
study was to measure students HOTS based on GC and present the data descriptively in the form of student profiles.

\section{MATERIALS AND METHODS}

The study was conducted in November-December 2018 at State Junior High School (SMPN) 1 South Tambun, Bekasi, West Java, Indonesia. The sample is students in the school and obtained by simple random sampling, the sample obtained was 128 students in grade $8^{\text {th }}$, consisting of 42 male students and 86 female students. In this study the method used is descriptive method. The Higher Order Thinking Skills (HOTS) instrument used is a valid and reliable instrument, previously developed (Ichsan, Sigit, \& Miarsyah, 2019b). The HOTS instrument consists of 12 items consisting of 3 aspects according to what was stated by Anderson et al. (2001) namely analyze, evaluate, and create. Each item has a range of scores 1-10. The instrument grid used can be seen in table 1 below. The GC aspects referred to are adapted from Kaiser \& Wilson, 2004 there are 6 aspects including (1) energy conservation (2) transportation (3) waste avoidance (4) consumption of daily product (5) recycling (6) vicarious, social behavior. These six aspects are included in the HOTS instrument. Data is presented descriptively both each aspect, each indicator, and each item.

Table 1. Aspect and Indicators HOTS instruments

\begin{tabular}{clc}
\hline \multicolumn{1}{c}{ Aspect } & \multicolumn{1}{c}{ Indicators } & Item \\
\hline C4 (Analyze) & $\begin{array}{l}\text { Analyzing the impact of using too much plastic } \\
\text { for the environment and health }\end{array}$ & 1,2 \\
& $\begin{array}{l}\text { Analyzing products that are environmentally } \\
\text { friendly and that are not environmentally friendly }\end{array}$ & 3,4 \\
& $\begin{array}{l}\text { based on green consumerism } \\
\text { Evaluating a product based on green }\end{array}$ & 5,6 \\
C5 (Evaluate) & $\begin{array}{l}\text { Consumerism } \\
\text { Critiquing a person's behavior based on green }\end{array}$ & 7,8 \\
& $\begin{array}{l}\text { consumerism concept } \\
\text { Creating a hypotheses (hypothesizing) about an }\end{array}$ & 9,10 \\
& $\begin{array}{l}\text { event related to environmental pollution } \\
\text { Creating a design (designing) of environmentally } \\
\text { friendly product/project based on the green } \\
\text { consumerism concept that has been delivered }\end{array}$ & \\
\hline
\end{tabular}

Source: Ichsan, Sigit, \& Miarsyah, (2019b

\section{RESULTS AND DISCUSSION}

The results showed that the average score of 128 students was 31.55 (after being converted to a scale of 0-100). Meanwhile, when viewed from gender, male scores average 30.77 and female get an average score of 31.93 . The more detailed scores of each aspect and indicator in detail can be seen in tables 2 and 3 below. Based on tables 2 and 3, it can be seen that the analyze (C4) aspect is the aspect with the highest score compared to the other aspects. Meanwhile on the indicator score, the highest score is obtained from the first indicator in $\mathrm{C} 4$. While the lowest indicator is in the second indicator in C6. The score for each item can be seen in table 4 below.

Table 2. Average HOTS scores for each aspect seen from all students, male and female

\begin{tabular}{llll}
\hline Aspect & All $(n=128)$ & Male $(\mathrm{n}=42)$ & Female $(\mathrm{n}=86)$ \\
\hline C4 (Analyze) & 3.81 & 3.72 & 3.85 \\
C5 (Evaluate) & 3.08 & 2.98 & 3.13 \\
C6 (Create) & 2.57 & 2.54 & 2.59 \\
\hline
\end{tabular}

Note: each aspect has a score range of $0-10$

Table 3. Average HOTS score for each indicator seen from all students, male and female

\begin{tabular}{|c|c|c|c|c|}
\hline Aspect & Indicators & $\begin{array}{l}\text { All } \\
(n=128)\end{array}$ & $\begin{array}{l}\text { Male } \\
(n=42) \\
\end{array}$ & $\begin{array}{l}\begin{array}{l}\text { Female } \\
(n=86)\end{array} \\
\end{array}$ \\
\hline \multirow[t]{3}{*}{ C4 (Analyze) } & $\begin{array}{l}\text { Analyzing the impact of } \\
\text { using too much plastic for } \\
\text { the environment and } \\
\text { health }\end{array}$ & 3.88 & 3.83 & 3.90 \\
\hline & $\begin{array}{l}\text { Analyzing products that } \\
\text { are environmentally } \\
\text { friendly and that are not } \\
\text { environmentally friendly }\end{array}$ & 3.74 & 3.61 & 3.81 \\
\hline & $\begin{array}{l}\text { based on green } \\
\text { consumerism }\end{array}$ & & & \\
\hline C5 (Evaluate) & $\begin{array}{l}\text { Evaluating a product } \\
\text { based on green } \\
\text { consumerism }\end{array}$ & 2.93 & 2.89 & 2.94 \\
\hline \multirow{3}{*}{ C6 (Create) } & $\begin{array}{l}\text { Critiquing a person's } \\
\text { behavior based on green } \\
\text { consumerism concept }\end{array}$ & 3.23 & 3.06 & 3.32 \\
\hline & $\begin{array}{l}\text { Creating a hypotheses } \\
\text { (hypothesizing) about an } \\
\text { event related to } \\
\text { environmental pollution }\end{array}$ & 2.60 & 2.54 & 2.63 \\
\hline & $\begin{array}{l}\text { Creating a design } \\
\text { (designing) } \\
\text { environmentally friendly } \\
\text { product/project based on } \\
\text { the green consumerism } \\
\text { concept that has been } \\
\text { delivered }\end{array}$ & 2.55 & 2.54 & 2.56 \\
\hline
\end{tabular}

Note: each indicator has a score range of 0-10

Table 4. Average HOTS score for each item

\begin{tabular}{|c|c|c|c|c|c|c|}
\hline No & GC Aspect & $\begin{array}{l}\text { HOTS } \\
\text { Aspect }\end{array}$ & Item & All $(n=128)$ & $\begin{array}{l}\text { Male } \\
(n=42)\end{array}$ & $\begin{array}{l}\text { Female } \\
(\mathrm{n}=86)\end{array}$ \\
\hline 1 & $\begin{array}{l}\text { Waste avoidance and } \\
\text { recycling }\end{array}$ & Analyze & Analyzing the impact of using plastic for the environment & 3.96 & 4.05 & 3.92 \\
\hline 2 & $\begin{array}{l}\text { Waste avoidance and } \\
\text { recycling }\end{array}$ & Analyze & Analyzing the impact of using Styrofoam for health and the environment & 3.80 & 3.62 & 3.88 \\
\hline 3 & $\begin{array}{l}\text { Consumption of daily } \\
\text { product }\end{array}$ & Analyze & $\begin{array}{l}\text { Analyzing the differences in two products based on the principle of } \\
\text { green consumerism }\end{array}$ & 3.45 & 3.48 & 3.44 \\
\hline 4 & $\begin{array}{l}\text { Consumption of daily } \\
\text { product }\end{array}$ & Analyze & $\begin{array}{l}\text { Analyzing the impact of using mosquito repellent spray, topical mosquito } \\
\text { repellent and mosquito coils }\end{array}$ & 4.03 & 3.74 & 4.17 \\
\hline 5 & $\begin{array}{l}\text { Consumption of daily } \\
\text { product and Recycling }\end{array}$ & Evaluate & $\begin{array}{l}\text { Evaluating a product that contains Eco label, for example the Forest } \\
\text { Stewardship Council (FSC) logo }\end{array}$ & 2.72 & 2.74 & 2.71 \\
\hline
\end{tabular}




\begin{tabular}{|c|c|c|c|c|c|c|}
\hline 6 & $\begin{array}{l}\text { Energy conservation and } \\
\text { transportation }\end{array}$ & Evaluate & $\begin{array}{l}\text { Evaluating use of vehicles that are more environmentally friendly } \\
\text { between electric and gasoline fueled vehicles }\end{array}$ & 3.13 & 3.05 & 3.17 \\
\hline 7 & $\begin{array}{l}\text { Waste Avoidance and } \\
\text { Recycling }\end{array}$ & Evaluate & $\begin{array}{l}\text { Criticizing the behavior of students who do not want to bring their own } \\
\text { bottles to reduce the use of plastic }\end{array}$ & 3.20 & 2.98 & 3.30 \\
\hline 8 & Vicarious, Social Behavior & Evaluate & $\begin{array}{l}\text { Criticizing the behavior of citizens who do not want to work together for } \\
\text { cleaning their environment }\end{array}$ & 3.27 & 3.14 & 3.34 \\
\hline 9 & Waste Avoidance & Create & Creating hypothesis about river pollutants based on the case & 2.66 & 2.60 & 2.69 \\
\hline 10 & Waste Avoidance & Create & $\begin{array}{l}\text { Creating hypothesis of the effect dumping large amounts of acid into the } \\
\text { soil on plants growth }\end{array}$ & 2.54 & 2.48 & 2.57 \\
\hline 11 & $\begin{array}{l}\text { Recycling and } \\
\text { Consumption of daily } \\
\text { product }\end{array}$ & Create & $\begin{array}{l}\text { Creating eco-friendly bag product designs, with details: basic materials, } \\
\text { manufacturing techniques, sketch drawings, estimated costs and } \\
\text { advantages and disadvantages }\end{array}$ & 2.59 & 2.71 & 2.53 \\
\hline 12 & Vicarious, Social Behavior & Create & $\begin{array}{l}\text { Creating a project design to solve the problem of the use of vacant land } \\
\text { for environmental sustainability }\end{array}$ & 2.51 & 2.36 & 2.58 \\
\hline
\end{tabular}

Note: each item has a score range of $0-10$

Based on table 4, it can be seen that the item with the highest score of all students is on item 4. Meanwhile the highest score on male is in item 1 , and female in item 4. Then if seen from the lowest score on all students there is item in 12 is equal to male, while for female in point 11. This shows that the create aspect is the hardest aspect and analyze aspect is the easiest aspect.

In environmental learning in schools there are not many who apply HOTS-based learning at school (Ichsan, Sigit, \& Miarsyah, 2019a). This is seen from the use of various learning devices that are still very traditional. When viewed in terms of material content, what is taught is a very conventional basic material. This makes students less able to analyze environmental problems (Camacho \& Legare, 2015; Turnip, Wahyuni, \& Tanjung, 2016). Basic material usually only accommodates lower abilities, from C1 - C3 (remember, understand, apply). While the global challenges in environmental problems require higher capabilities than just C1-C3. Therefore HOTS is very necessary and relevant to the conditions of global environmental problems that need to be solved (Boholano, 2017; Genc, Genc, \& Rasgele, 2018; Paço \& Rodrigues, 2016). Based on the results of the study, many students have low HOTS, especially in the Create (C6) aspect. This is because in learning at school, students are usually only taught to understand the concepts that already exist, without being given the task to create solutions to environmental problems (Fitriani, Adisyahputra, \& Komala, 2018; Jewpanich \& Piriyasurawong, 2015; Vidergor \& Krupnik-Gottlieb, 2015).

Create solutions in environmental problems, for example, are related to excessive use of plastic. Students can be asked to create a bag that is more environmentally friendly with ingredients derived from recycling. This is very possible in the classroom using the Project Based Learning model (Ito \& Kawazoe, 2015; Koh, Chai, Wong, \& Hong, 2015; Seechaliao, 2017; Şener, Türk, \& Taş, 2015). So that in addition to students being trained in HOTS skills in terms of creating, there are also products that are produced that can even be of economic value. In terms of designing a project to overcome vacant land, students can be trained to design a mini park at school. This will help students to practice their ability to create (Gündüz et al., 2016; Hemmerich, Hoepner, \& Samelson, 2015; K. Lee \& Lai, 2017).
Points on other aspects of create (C6) are related to making hypotheses. On both points that ask students to make a hypothesis also still have a low score. That is because information in terms of environmental problems is still little. Students are required to obtain as much information as possible, then obtain various existing theories about the environment, so that they can create a hypothesis. That is because making a hypothesis is an ability that must combine various facts and theories that exist, into a hypothesis. If information about environmental problems is still not mastered by students, students will have difficulty making a hypothesis (DeSchryver, 2017; Saido et al., 2015; Smith \& Darvas, 2017).

Besides create (C6), another low aspect is the evaluate (C5) aspect. Students have difficulty determining whether an item is in accordance with the concept of Green Consumerism (GC) or not. This is because the information held by students in terms of GC is still very low. Information such as eco labels is an important one (Dekhili \& Achabou, 2015; Saouter, De Schryver, Pant, \& Sala, 2018; Weitzman \& Bailey, 2018). That is because the products currently in circulation are not all having an eco label. In terms of evaluating the habit of using a gasoline-fueled vehicle, students also still don't know much information. Although HOTS scores are higher in terms of fuel use than eco labels. This can be the basis for developing teaching materials or learning media that contain eco label information.

While still in the evaluate (C5) aspect, HOTS is high related to criticizing the habits of students who do not want to bring their own drinking bottles. Besides that, it is also related to criticizing the people who do not want to participate in cleaning the environment. In these 2 points, students still have more information than the problem of eco labels and environmentally friendly transportation. Even so, the ability of students to argue is still low. This can be seen from the score that is still relatively low, even though the problem is a problem that is very close to everyday life (Hidayati \& Wuryandari, 2012; Istiana \& Awaludin, 2018; Sadiqin, Sholahuddin, \& Santoso, 2017; Suhendar \& Wahyuni, 2018; Vidergor, 2018).

In the analyze (C4) aspect, the HOTS score of students is relatively higher. The highest items are related to the use of insect repellent and the use of plastic. This is because information about this matter is relatively more, compared to information about Styrofoam and the 
principles in choosing GC-based products. This is an important point where students should be trained in learning to analyze the two things. The use of Styrofoam as a familiar food wrap also supports the results of the above research. This shows that students and the public in general still do not understand much of the negative effects of using Styrofoam (Avan, Aydinli, Bakar, \& Alboga, 2011; Hama \& Hilal, 2017; Yeow, Dean, \& Tucker, 2014). This is related to students' ability to determine the quality of a product based on GC principles.

In the end, environmental learning must be HOTS-based to overcome existing problems. Environmental learning can be in a variety of ways, it can be through formal learning specifically to discuss the environment in one subject. Environmental learning can also be part of a Biology subject or Natural Science subject at school. In essence, environmental learning must be packaged according to HOTS and GC principles. That is because GC problems are the focus of problems that must be solved both at the elementary, secondary and university level. Students must be actively involved in environmental learning so that learning is better (Buzov, 2014; Nissim, Weissblueth, Scott-Webber, \& Amar, 2016; Sesen \& Tarhan, 2010).

\section{CONCLUSION}

Based on the results of the study, students HOTS scores of GC-based were still relatively low. This is due to the lack of information obtained by students regarding the GC. This indicates that students HOTS based on GC must be improved through the development of learning. Environmental learning in schools should also not only discuss basic concepts but also discuss current issues.

\section{REFERENCES}

Akenji, L. (2014). Consumer scapegoatism and limits to green consumerism. Journal of Cleaner Production, 63, 13-23. https://doi.org/10.1016/j.jclepro.2013.05.022

Anderson, L. W., Krathwohl, D. R., Airiasian, W., Cruikshank, K. A., Mayer, R. E., \& Pintrich, P. R. (2001). A taxonomy for learning, teaching and assessing: A revision of Bloom's Taxonomy of educational outcomes: Complete edition. New York: Longman.

Avan, C., Aydinli, B., Bakar, F., \& Alboga, Y. (2011). Preparing Attitude Scale to Define Students' Attitudes about Environment, Recycling, Plastic and Plastic Waste. International Electronic Journal of Environmental Education, 1(3), 179-191.

Boholano, H. B. (2017). Smart Social Networking: 21st Century Teaching And Learning Skills. Research in Pedagogy, 7(1), 21-29. https://doi.org/10.17810/2015.45

Buzov, I. (2014). Social Network Sites as Area for Students' Pro-environmental Activities. Procedia Social and Behavioral Sciences, 152, 1233-1236. https://doi.org/10.1016/j.sbspro.2014.09.304

Camacho, D. J., \& Legare, J. M. (2015). Opportunities to Create Active Learning Techniques in the Classroom. Journal of Instructional Research, 4, 38-45.
Costa, E., Montemurro, D., \& Giuliani, D. (2018). Consumers' willingness to pay for green cars: a discrete choice analysis in Italy. Environment, Development and Sustainability, 1-18. https://doi.org/10.1007/s10668-018-0141-z

Dekhili, S., \& Achabou, M. A. (2015). The Influence of the Country-of-Origin Ecological Image on Ecolabelled Product Evaluation: An Experimental Approach to the Case of the European Ecolabel. Journal of Business Ethics, 131(1), 89-106. https://doi.org/10.1007/s10551-014-2261-1

Derman, A., Sahin, E., \& Hacieminoglu, E. (2016). Does Outdoor Education Make any Difference in Environmental Literacy of Pre-service Classroom Teachers? International Journal of Environmental \& Science Education, 11(15), 8491-8506.

DeSchryver, M. (2017). Using the Web as a Higher Order Thinking Partner: Case Study of an Advanced Learner Creatively Synthesizing Knowledge on the Web. Journal of Educational Computing Research (Vol. 55). https://doi.org/10.1177/0735633116667356

Fitriani, U., Adisyahputra, A., \& Komala, R. (2018). Eco-friendly website development in biology learning based on project activities on environmental pollution. Biosfer: Jurnal Pendidikan Biologi, 11(1), 32-46. https://doi.org/https://doi.org/10.21009/biosferjpb.11-1. 4

Genc, M., Genc, T., \& Rasgele, P. G. (2018). Effects of nature-based environmental education on the attitudes of 7 th grade students towards the environment and living organisms and affective tendency. International Research in Geographical and Environmental Education, 27(4), 326-340. https://doi.org/10.1080/10382046.2017.1382211

Gu, W., Chhajed, D., Petruzzi, N. C., \& Yalabik, B. (2015). Quality design and environmental implications of green consumerism in remanufacturing. International Journal of Production Economics, 162, 55-69. https://doi.org/10.1016/j.ijpe.2014.12.040

Gündüz, A. Y., Alemdağ, E., Yaşar, S., \& Erdem, M. (2016). Design of a Problem-Based Online Learning Environment and Evaluation of its Effectiveness. The Turkish Online Journal of Educational Technology, 15(3), 49-57. https://doi.org/10.1017/CBO9781107415324.004

Hama, S. M., \& Hilal, N. N. (2017). Fresh properties of self-compacting concrete with plastic waste as partial replacement of sand. International Journal of Sustainable Built Environment, 6(2), 299-308. https://doi.org/10.1016/j.ijsbe.2017.01.001

Hemmerich, A. L., Hoepner, J. K., \& Samelson, V. M. (2015). Instructional Internships: Improving the teaching and learning experience for students, interns, and faculty. Journal of the Scholarship of Teaching and Learning, 15(3), 104. https://doi.org/10.14434/josotl.v15i3.13090

Hidayati, N., \& Wuryandari, A. I. (2012). Media Design for Learning Indonesian in Junior High School Level. Procedia - Social and Behavioral Sciences, 67, 490-499. https://doi.org/10.1016/j.sbspro.2012.11.354

Ichsan, I. Z., Sigit, D. V., \& Miarsyah, M. (2019a). 
Environmental Learning Based on Higher Order Thinking Skills: A Needs Assessment. International Journal for Educational and Vocational Studies, 1(1), 21-24. https://doi.org/10.29103/ijevs.v1i1.1389

Ichsan, I. Z., Sigit, D. V., \& Miarsyah, M. (2019b). Students , Higher Order Thinking Skills in Environmental Learning : Develop Assessment Based on Green Consumerism. Journal of Educational Science and Technology (EST), 5(1), 9-19.

Istiana, R., \& Awaludin, M. T. (2018). Enhancing biology education students ability to solve problems in environmental science material through inquiri model-based lesson study. Biosfer: Jurnal Pendidikan Biologi, 11(1), 57-66. https://doi.org/https://doi.org/10.21009/biosferjpb.11-1. 6

Ito, H., \& Kawazoe, N. (2015). Active Learning for Creating Innovators: Employability Skills beyond Industrial Needs. International Journal of Higher Education, 4(2), 81-91. https://doi.org/10.5430/ijhe.v4n2p81

Jensen, J. L., McDaniel, M. A., Woodard, S. M., \& Kummer, T. A. (2014). Teaching to the Test...or Testing to Teach: Exams Requiring Higher Order Thinking Skills Encourage Greater Conceptual Understanding. Educational Psychology Review, 26(2), 307-329. https://doi.org/10.1007/s10648-013-9248-9

Jewpanich, C., \& Piriyasurawong, P. (2015). Project-Based Learning Using Discussion and Lesson-Learned Methods via Social Media Model for Enhancing Problem Solving Skills. International Education Studies, 8(6), 24-31. https://doi.org/10.5539/ies.v8n6p24

Kaiser, F. G., \& Wilson, M. (2004). Goal-directed conservation behavior: The specific composition of a general performance. Personality and Individual Differences, 36(7), 1531-1544. https://doi.org/10.1016/j.paid.2003.06.003

Kartikaningtyas, V., Kusmayadi, T. A., \& Riyadi, R. (2018). The effect of brain based learning with contextual approach viewed from adversity quotient The effect of brain based learning with contextual approach viewed from adversity quotient. Journal of Physics: Conference Series, 1022.

Koh, J. H. L., Chai, C. S., Wong, B., \& Hong, H. Y. (2015). Design Thinking and 21st Century Skills. In Design Thinking for Education: Conceptions and Applications in Teaching and Learning (pp. 1-131). https://doi.org/10.1007/978-981-287-444-3

Koutsoukos, M., Fragoulis, I., \& Valkanos, E. (2015). Connection of environmental education with application of experiential teaching methods: A case study from Greece. International Education Studies, 8(4), 23-28. https://doi.org/10.5539/ies.v8n4p23

Lee, K., \& Lai, Y. (2017). Facilitating higher-order thinking with the flipped classroom model: a student teacher's experience in a Hong Kong secondary school. Research and Practice in Technology Enhanced Learning, 12(1). https://doi.org/10.1186/s41039-017-0048-6

Lee, S. M. (2014). The relationships between higher order thinking skills, cognitive density, and social presence in online learning. Internet and Higher Education, 21, 41-52. https://doi.org/10.1016/j.iheduc.2013.12.002

McCarthy, B., \& Liu, H. B. (2017). Food waste and the "green" consumer. Australasian Marketing Journal, $25(2)$,

126-132. https://doi.org/10.1016/j.ausmj.2017.04.007

Meyer, A. (2016). Heterogeneity in the preferences and pro-environmental behavior of college students: The effects of years on campus, demographics, and external factors. Journal of Cleaner Production, 112, 3451-3463.

https://doi.org/10.1016/j.jclepro.2015.10.133

Narayanan, S., \& Adithan, M. (2015). Analysis of Question Papers in Engineering Courses with Respect to HOTS (Higher Order Thinking Skills). American Journal of Engineering Education, 6(1), 1-10.

Nissim, Y., Weissblueth, E., Scott-Webber, L., \& Amar, S. (2016). The Effect of a Stimulating Learning Environment on Pre-Service Teachers' Motivation and 21st Century Skills. Journal of Education and Learning, 5(3), 29. https://doi.org/10.5539/jel.v5n3p29

Paço, A., \& Rodrigues, R. G. (2016). Environmental activism and consumers' perceived responsibility. International Journal of Consumer Studies, 40(4), 466-474. https://doi.org/10.1111/ijcs.12272

Sadiqin, I. K., Sholahuddin, A., \& Santoso, U. T. (2017). Students ' Difficulties on Science Learning with Prototype Problem-Solving Based Teaching and Learning Material : A Study Evaluation of Development Research. Advances in Social Science, Education and Humanities Research, 100, 279-282.

Saido, G. M., Siraj, S., Nordin, A. B. Bin, \& Amedy, O. S. A. (2015). Higher Order Thinking Skills Among Secondary School Students in Science Learning. The Malaysian Online Journal of Educational Science, 3(3), 13-20.

Saouter, E., De Schryver, A., Pant, R., \& Sala, S. (2018). Estimating chemical ecotoxicity in EU ecolabel and in EU product environmental footprint. Environment International, 118(March), 44-47. https://doi.org/10.1016/j.envint.2018.05.022

Seechaliao, T. (2017). Instructional Strategies to Support Creativity and Innovation in Education. Journal of Education and Learning, 6(4), 201-208. https://doi.org/10.5539/jel.v6n4p201

Şener, N., Türk, C., \& Taş, E. (2015). Improving Science Attitude and Creative Thinking through Science Education Project: A Design, Implementation and Assessment. Journal of Education and Training Studies, 3(4), 57-67. https://doi.org/10.11114/jets.v3i4.771

Sesen, B. A., \& Tarhan, L. (2010). Promoting active learning in high school chemistry: Learning achievement and attitude. Procedia - Social and Behavioral Sciences, 2(2), 2625-2630. https://doi.org/10.1016/j.sbspro.2010.03.384

Shabani, N., Ashoori, M., Taghinejad, M., \& Beyrami, H. (2013). The study of green consumers ' characteristics and available green sectors in the market. International Research Journal of Applied and Basic 
Sciences, 4(7), 1880-1883.

Smith, V. D., \& Darvas, J. W. (2017). Encouraging Student Autonomy through Higher Order Thinking Skills. Journal of Instructional Research, 6, 29-34. Retrieved from http://ezproxy.lib.uconn.edu/login?url=https://search.e bscohost.com/login.aspx?direct=true \&db=eric\&AN=EJ 1153306\&site=ehost-live

Suhendar, S., \& Wahyuni, A. (2018). Achievement and response of students at favorite junior high schools in sukabumi on trends in international mathematics and science study (timss) questions. Biosfer: Jurnal Pendidikan Biologi, 11(2), 126-133. https://doi.org/https://doi.org/10.21009/biosferjpb.v11n 2.126-133

Turnip, B., Wahyuni, I., \& Tanjung, Y. I. (2016). The Effect of Inquiry Training Learning Model Based on Just in Time Teaching for Problem Solving Skill. Journal of Education and Practice, 7(15), 177-181. Retrieved from http://search.ebscohost.com/login.aspx?direct=true\&db $=$ eric $\& \mathrm{AN}=\mathrm{EJ} 1103095 \&$ site=ehost-live

Vidergor, H. E. (2018). Effectiveness of the multidimensional curriculum model in developing higher-order thinking skills in elementary and secondary students. Curriculum Journal, 29(1), 95-115. https://doi.org/10.1080/09585176.2017.1318771

Vidergor, H. E., \& Krupnik-Gottlieb, M. (2015). High order thinking, problem based and project based learning in blended learning environments. In Applied Practice for Educators of Gifted and Able Learners (pp. 217-232). https://doi.org/10.1007/978-94-6300-004-8_11

Watson, L., Hegtvedt, K., Johnson, C., Parris, C., \& Subramanyam, S. (2017). When Legitimacy Shapes Environmentally Responsible Behaviors: Considering Exposure to University Sustainability Initiatives. Education $\quad$ Sciences, 13 (1), https://doi.org/10.3390/educsci7010013

Weitzman, J., \& Bailey, M. (2018). Perceptions of aquaculture ecolabels: A multi-stakeholder approach in Nova Scotia, Canada. Marine Policy, 87(June 2017), 12-22. https://doi.org/10.1016/j.marpol.2017.09.037

Yeow, P., Dean, A., \& Tucker, D. (2014). Bags for Life: The Embedding of Ethical Consumerism. Journal of Business $\quad$ Ethics, 125(1), 87-99. https://doi.org/10.1007/s10551-013-1900-2 